je tá dnešná, je stále životaschopná vytvárat’ priestor pre skutočné praktické riešenia, napriek tomu, že je podla súčasných vedeckých tendencií na ústupe.

Peter Jančiar

\author{
Mgr. Peter Jančiar \\ Katedra filozofie \\ Filozofická fakulta \\ Univerzita Konštantína Filozofa v Nitre \\ Hodžova 1 \\ 94974 Nitra \\ pjanciar@ukf.sk
}

\title{
Carrie B. Dohe: Jung's Wandering Archetype. Race and Religion in Analytical Psychology
}

London, Routledge, 2016, p. 266.

American historian of religions, Carrie B. Dohe, a guest researcher in Department of Religious Studies at University of Marburg, Germany (2010-2015), investigates the use and application of contemporary discourse about the divine and the way it justifies social and political aims of certain enviromentalist groups in Germany, Europe and USA. Dohe's Jung's Wandering Archetype describes in detail reception of Jung's phylogenetic, historically layered unconscious in social sciences, new (reconstructionist) religiosities and, by implication, in politics. New religiosities (Ásatrú, Odinism, both ethnic and racist Heathenism, Norse Paganism, Robert Bly's Mythopoetic Men's Movement or Wicca) not only refer to the old Germanic myths (Poetic Edda and Prose Edda as described in the chap. 2), but put unusual stress on "ancestry" and refer to Jung's phylogenetic unconscious as well. In other words Dohe links new forms of Western religiosity with Jung's discourse where the scientific and the religious are skillfully intertwinned. According to the author post-war Western Heathenism ("loosely networked contemporary religious movement based on ancient Germanic religious traditions", Dohe, 210-211), in whose theology and politics "race" and "ancestry" play the central role, draws from Jung's unconscious and especially from his essay Wotan (1936). Referring to Jung, these movements construct a new, race-delimited religion.

There were attempts to place Jung within German holistic völkisch thinking (Richard Noll, Petteri Pietikäninen): "As Ann Harrington and 
Mitchell G. Ash have demonstrated (...) organic, holistic ideas are not in themselves fascist or 'reactionary'. A number of respected German scientists and scholars (...) were concerned with achieving Wholeness (Ganzheit) in culture and society" (Pietikäninen 2000, 538). But, as Petteri Pietikäinen has recently demonstrated, Jung's very specific discourse enabled him to leave "German Revolution" and its Weltanschauung and to enter the English-speaking world. In mid-1930s "Jung didn't want to risk his growing reputation in the Anglo-American world by adhering too closely to openly völkisch doctrines (...). Many Anglo-Americans were attracted to Jung's individual-centered, teleological, and hence forward-looking ideas. Jung had Germanic 'depth' and profundity, but he also had affinities with Anglo-American individualism and pragmatism. (...) Jung was quite successful in his attempt to present himself to Anglo-Americans as a politically neutral Swiss doctor and scientist" (Pietikäinen 2000, 535-536). But soon after the war Jung had been accused not only from collaboration with Nazis but also from founding new pseudo-religious cult. ${ }^{1}$

Jung's affinities with Anglo-American world were confirmed by H. G. Baynes' book Analytical Psychology and the English Mind (1950). But at the same time his emphasis on both individual and collective Ganzheit makes him one of the exponents of specifically German 19th century holistic völkisch thought (during early 1930s Jung interpreted "Germanic revolution" in psychologico-archetypal terms as a national individuation). Moreover, some of his statements during his Nietzschean seminars ("I must say that I am very grateful to the Germans for their paganistic movement, at the head of which is my friend Professor Hauer who taught us the Tantric Yoga, and who has now become a saviour of the fools" (Jung 1988, 813)) justify today's Heathenists' claims to make him their "guru". This is exactly the link between Jung's concepts (collective phylogenetic unconscious, individuation, Ganzheit) and the contemporary Heathenism that Dohe's contextualizes and interprets as a continuum.

For Dohe, Germanic aspect of Jung's thought found its heir in post-war racialist and ethnic Heathenism: “(...) Americam Heathenism has its roots in the more virulently racist end of the Heathen spectrum, specifically

Even though Dohe does not affirm anything like that, such accusations are certainly due to Jung's capacity to combine scientific and religious discourse. According to Shamdasani accusations of Jung's attempts to found a cult initiated by A. C. Meier's book Ancient Incubation and Modern Psychotherapy (1949) where Meier affirms that Jung's discoveries have to do with ancient healing cults. Meier asks whether modern psychotherapy is a cult. Accusations of esoteric cult foundation existed still in 1970s (James Webb). Shamdasani (1998, 4-6). 
Odinist Fellowship of Else Christensen (1913-2005). An adherent of Danish national-bolshevist Nazism and the ideas of the Australian Church of Odin founder Rud Mills, Christensen founded the Odinist Fellowship in 1969 (...). Christensen saw in Jungian theory support for her belief in an Aryan 'folk soul', which she interpreted as a genetically inherited, racially specific collective unconscious. The origin of Odinism, she claimed, 'is in our race, its principles encoded in our genes'” (Dohe 2015, 215). Thus it seems that whereas analytical psychology rejected this aspect of Jung's thought ${ }^{2}$, Heathens appropriated it, mixed it with Germanic and Norse ancient mythology and produced their own scientic-religious theories (McNallen's Metagenetics etc.) and today enter international politics. ${ }^{3}$ In other words, if Jung spiritualized race and racialized spirit, then post-war Heathenism follows the same direction.

What is the new perspective Dohe opens for us? Dohe follows George Mosse's fundamental thesis about post-WW II secular religiosity:

"The impact of racism in modern times derives from the fact that it became a secular religion based upon science and history; it laid claim to the best of two worlds, that of science, which provided new "truths" from the eighteenth century onward, and that of history, which forged a link to traditions which were fast dissolving in the modern world. ${ }^{4}$

Western culture and states that "etnic and racist Heathens combine certain ideas about science, race and religion to construct a new, race-delimited religion, appropriating Jungian psychology to further this aim" (Dohe 2015, 210).

2 '(...) Jung's attitudes to women, blacks, so-called 'primitive' cultures, and so forth are now outmoded and unacceptable. (...) We can now see how Jung converted prejudice into theory" Samuels (2008, 2-3).

3 Dohe discusses reasons of considerable resistance to Obama as a presidential candidate and suspicions regarding his national identity (p. 241-242): "the categories of race and religion are blurred in many American minds (...) American population still clings to the myth that the United States is a white, Christian nation, and its leader should therefore reflect that state of his own being" (Dohe, 241-242). It pays also attention to main theses of Sarazzin's book Deutschland schafft sich ab (2010) about Muslim migration to Germany and phenomenon of German PEGIDA (Dohe, 240) and later she mentions, affair of so-called "Kennewick man" in the USA (Dohe, 230-235), McNallen's "Metagenetics" (Dohe, 221-227) and possible re-appareance of racism due to the lack of natural resources on the planet Earth (Dohe, 240).

4 George L. Mosse, 1988, p. 85. 


\section{Chapter by chapter}

The book is divided into 9 chapters. The reader is introduced to the problem in the two first chapters: "Something Like a Wotan" (1-19) and "Because We Germanic People Still Have a Genuine Barbarian in Us" (20-50). Here reader is introduced to Jung's essay "Wotan". For Dohe Wotan constitutes not only depth-psychological perspective on National Socialism, but contains Jung's pre-First World War ideas as well. Here the "esence" (authenticity) of Germanic peoples is described. Here Jung drew from and expanded 2.000-year-old Roman discourse on German barbarian which was 1.500 later appropriated by German humanists. $19^{\text {th }}$-century German artists and intellectuals shifted negative characteristicts ascribed to Germanic tribes to those peoples many Europeans wanted to colonize. In addition philologists united Rome and Germany creating larger linguistic and racial category of "Aryan" family whose oppositional force constitute "Jews" or Semites. The same elements reappeared also in Jung's works on so-called primitive peoples, Jews and people of Germanic descent.

The third chapter Dohe introduces by Joachim Wach's differentiation between master and disciple to see whether Jung should be called scientist or prophet (after the World War II Jung was frequently viewed as a founder of new cult, prophet or religious leader). In this way Dohe demonstrates that the image of Jung cultivated by Jung himself and his disciples fits the model of "master" and contextualizes further development of Jung's theory after the WW II. In Dohe's view Jung

"sought to position his work between and inclusive science and spirituality as a way to help his contemporaries out of the crisis of meaning then reigning in Europe" and "to form a bridge between faith and reason (...) incorporated into his theory several key concepts from the science of religion, including evolutionism, mana and Ergriffenheit" and "placed his work within the field of holistic science, which was opposed to the competing mechanistic viewpoint" (Dohe, 244).

In the fourth chapter Dohe explores Jung's theory of polygenetic unconscious and the archaic level of mind. Here we can find differentiation between "dark-skinned" and "noble savages" that Jung found in scholarly works on "primitive religion". Jung's view on archaic mind was ambivalent: on the one hand he viewed it as a repository of instinctual collective forces that could overwhelm an individual (and thus leading to psychosis or dangerous collective movements), on the other hand he viewed it as a source of vitality, creativity, originality and, on collective level, progressive forces 
of history. Whereas negative aspects of archaic mind were negatively coded by Jung, the positive ones are not negatively coded in Jung's theory (symbol of the Self, the sun, transcends human realm).

In the fifth chapter Dohe continues exploring Jung's concept of primitivity as applied to "Germanic" and "Jewish" psychology and compares it with Freud's concept of primitivity. According to Dohe Freud displaced the image of "dark-skinned" European from European "other" (Jew) to non-European races and ethicities and attempted to align Jew and Germanic under the rubric of civilized. Jung, on the other hand, split all three groups apart - reserving civilized for Germanic-Christian psyche.

In the sixth chapter there is an in-depth analysis of Wotan. Dohe explores one of the reigning motifs of the essay is Ergriffenheit (phenonomenon of both individual and collective psyche explored by Rudolf Otto in his Das Heilige (1917) and explored by Dohe in one of her articles ${ }^{5}$ ) in connection with Rudolf Otto's and Jakob Wilhelm Hauers' work. In Wotan Jung holds that under National Socialism Germany was going through the intensified collective individuation process (Pietikaninen uses expression "national individuation") and thus psychologized history of German people.

In the seventh chapter Dohe views in detail Jung's rejection of Hitler as a leader of Germans and as a mouthpiece of collective rebirth. Whereas in Wotan Hitler was described as a mouthpiece and prophet of collective archaic unconscious (Führer), later Jung described him as an effeminate hysteric. According to Dohe "this and other reversals were probably driven more by the need to protect himself from allegation Jung faced after the war that he had sympathized with the Nazis" (Dohe, 245). The chapter also explores post-war Jung's writing of Wotan and Yahweh and considers Jung's views on "Germanic" and "Jewish" psychology as relatively stable.

The eighth chapter explores resonance of Jung's concept of primitivity and archaic level of psyche in contemporary Heathenism or Ásatrú. Dohe mentions countries like Germany or Great Britain but most of her attention is paid to the USA. Since the post-war decades Jung's concept of primitive became very attractive for both ethnic and racist branches of Heathenism "members of which often claim that the current revival of Germanic religion is due to a genetically inherited 'folk-soul', born in the biological makeup of descendants of Northern Europe" (Dohe, p. 246). Dohe does not forget to mention that contemporary Heathenism diverge from Jung's theory in many respects: 1) contemporary Heathenism follows the same trajectory as a Germanic revival movement one hundred years ago, i.e. it is opposed to Christianity (whereas Jung's view bore

5 Dohe 2011 
similarities with Germanized Christianity of Wagnerian Circle), 2) some Heathens desengage Jung's theory of archetypes from the influence of climate and geography and argue in favour of trans-historical and deterritorialized racial/psychic essence of humans. In this final chapter Dohe proves that Jung's writings about Germanic people express his belief that climate and geography exerted determining influence in their psychology and help to shape Volksgeist.

Importance of this work consists in the fact that it belongs to quite small number of works that pay attention to a link between race (she elucidates "Aryan myth" in the West, notions like Germane, Germanic, Teutonic, barbarian, primitive etc.) and psyche in Jung. Like this such studies shed light to older works ${ }^{6}$. In this particular case, Dohe links Jung to disciplines of his time like theology, ethnology, comparative mythology or today's studies of racialism or paganism. What Dohe does not mention is Jung's German precursor of Völkerpsychologie (Lazarus, Steinthal, Wundt) founded in mid-1850s around "the notion of individual vs collective spirit (Geist) and soul (Seele)" whose "underlying question was whether it was possible to study collective mental phenomena. (...) Lazarus and Steinthal (1860) defined the Volksgeist (or collective spirit) as 'the inner activity, according to content as well as form, which each individual has in common in terms of inner activity'. (...) Volksgeist could be objectively studied" (Diriwächter 2004, 89). But Dohe analyzes concept of primitivity, concept of archaic psyche and their resonance within European and North-American societies in the end of $20^{\text {th }}$ and at the beginning of the $21^{\text {st }}$ centuries. In her view late $19^{\text {th }}$-century scientists (context of Jung ground-breaking Wandlungen und Symbole der Libido, 1912) worked with evolutionary model according to which in the distant past there was a psychic unity of humanity: "underlying the claim of psychic unity is that monogenesis, the belief in a common ancestry of all humanity" (Dohe, 88). This theory was further supported by the recapitulation theory of Ernst Haeckel who proposed that "ontogeny recapitulates phylogeny" (1866). Both concepts were appropriated by anthropologists in their concepts of "primitivity" and concept of recapitulation was appropriated in theories on the origin and essence of religion. Jung read all these works.

Whereas Völkerpsychologie did not work with the concept of primitivity, in the late 19th century the notion of collective soul got significantly enlarged and deepened. As Dohe's works elucidates, it existed and evolved out of both Jungian and religious concepts.

$6 \quad$ In Dohe's case it is quite rich intellectual production of Chilean writer and diplomat Miguel Serrano (1917 - 2009) usually denominated as "esoterist Hitlerist". 
Dohe's work has also significant linguistic aspect (high respect to original German terminology). Dohe used both original German-written works and their English translations: "the patterns of mistranslations, deletions, and misleading editorial remarks found throughout Collected Works and Jung's Letters cannot simply be dismissed as innocent mistakes made by Jung's translators and editors" (Dohe, 246). In this respect her work belongs to number of today's English-written philosophical and depth-psychological works (for ex. Martin Liebscher, Matthew Bell, Angus Nicholls, Paul Bishop, Wolfgang Giegerich) who attempt to delve into Germanic studies in more depth, view English translations with certain suspicion and usually offer various alternative translations and original quotations in German.

Aleš Vrbata

\section{References}

DIRIWÄCHTER, R. (2004). Völkerpsychologie: The Synthesis that Never Was. In: Culture Psychology, 10-28.

DOHE, C. B. (2011). Wotan and the 'archetypal Ergriffenheit'. Mystical union, National Spiritual Rebirth and Culture-Creating Capacity in C. G. Jung's 'Wotan' Essay. In: History of European Ideas, 37, 344-356.

JUNG, C. G (1988). Nietzsche's Zarathustra. Notes of the Seminar given in 1934-1938 by C. G. Jung. Vol. 2. Pricenton: Princeton University Press.

MOSSE, G. L. (1988). The Culture of Western Europe: The Nineteenth and Twentieth Centuries. Chicago: Rand McNally, 1988.

PIETIKÄINEN P. (2000). Volk and Its Unconscious: Jung, Hauer, and the 'German Revolution'. In: Journal of Contemporary History, (35), 523-539.

SAMUELS, A (2008). New Developments in Post-Jungian Thought, In: Polly YoungEisendrath - Terence Dawson (eds.): Cambridge Companion to Jung. 2008, 2-3. SHAMDASANI, S. (1998) Cult Fiction: C. G. Jung and the Founding of Analytical Psychology. London: Routledge, 1998.

\section{Aleš Vrbata, PhD.}

State University of Feira de Santana

Literature and Cultural Diversity Post-Graduate Department

AVENIDA TRANSNORDESTINA S/N

Caixa Postal: $252-294$

CEP: 44.036-900

Feira de Santana

Brasil

alesvrbata@hotmail.com 